\title{
ANALISIS RANTAI PASOKAN KOMODITAS FLORIKULTURA SEBAGAI UPAYA PENINGKATAN EKONOMI MASYARAKAT DI KABUPATEN BANDUNG BARAT
}

\author{
Oleh \\ IVONNE AYESHA \\ Fakultas Pertanian, Universitas Ekasakti \\ e-mail: ayesha_ivonne@yahoo.co.id
}

\begin{abstract}
Abstrak
Penelitian ini dilakukan di Desa Cihideung, Kecamatan Parongpong, Kabupaten Bandung Barat dengan menggunakan menggunakan metode survei, dengan pendekatan desk research terhadap kajian lapangan. Objek penelitian adalah pelaku agribisnis florikultura dari hulu sampai hilir yang berada dalam rantai pasokan. Hasil wawancara dan observasi tentang fenomena kajian lapangan dianalisis secara deskriptif. Hasil analisis dijadikan dasar untuk membuat gambaran secara sistematis, faktual dan akurat mengenai fakta-fakta, sifat-sifat serta hubungan fenomena yang diteliti secara objektif tentang agribisnis florikultura. Model rantai pasokan agribisnis florikultura, memiliki dua aliran, yaitu aliran produk dan aliran uang. Aliran produk berupa bunga pot dan bunga potong, sedangkan aliran uang adalah perpindahan uang mulai dari konsumen samai pada pelaku paling hulu dalam sistem rantai pasokan florikultura. Terdapat tiga rantai pasokan dalam agribisnis florikultura, baik bunga pot maupun bunga potong. Panjangnya rantai pasokan tersebut, menyebabkan perbedaan harga (margin) antar harga produk yang diterima petani (produsen) dengan harga yang dibayarkan konsumen memiliki perbedaan yang sangat jauh. Kondisi ini disebabkan pasar produk bunga tidak terstruktur dan petani sangat tergantung kepada pengepul di desa sebagai tempat menjual bunganya. Berdasarkan temuan dan hasil analisis rantai pasokan agribisnis florikultura tersebut, maka upaya yang dapat dilakukan untuk meningkatkan pendapatan petani (produsen) agrbisnis florikultura adalah: 1) Usahatani pada teknologi (Non-land base agriculture, 2) Kredit pertanian, 3) Budaya enterpreneur, dan 4) Pusat pasar bunga di tingkat desa atau kecamatan.
\end{abstract}

Kata kunci: rantai pasokan, florikultura, ekonomi masyarakat

\section{PENDAHULUAN}

Florikultura merupakan salah satu subsektor yang memiliki potensi sebagai pusat pertumbuhan baru sektor pertanian. Terdapat tiga alasan yang mendukung hal tersebut diatas, yaitu (1). Potensi keragaman jenis tanaman hias yang mempunyai nilai ekonomi tinggi, (2). Potensi pasar produk tanaman hias baik domestik maupun ekspor, dan (3). Potensi ketersediaan lahan bagi pengembangan tanaman hias di Indonesia yang masih cukup luas. Oleh sebab itu, menurut (Kahar, 1997), tujuan dari pengembangan bunga potong diarahkan untuk meningkatkan pendapatan petani melalui peningkatkan produktifitas dan produksi serta mutu.

Direktorat Jenderal Bina Produksi Hortikultura (2011) menyebutkan kebutuhan pasar dalam dan luar negeri pada kenyataannya tidak dapat dipenuhi hingga masih diperlukan impor 5-15\% dari total volume yang dibutuhkan. Bahkan, sejak 10 tahun terakhir permintaan akan bunga/Tanaman Bunga dan tanaman hias meningkat pesat dari tahun ke tahun, di kota-kota besar tercatat lebih dari 50 juta tangkai bunga/Tanaman Bunga potong dibutuhkan setiap tahun untuk mencukupi permintaan pasar ibu kota.

Provinsi Jawa Barat berdasarkan pengelompokkan yang dilakukan oleh dinas pertanian, termasuk pada wilayah sentra produksi tanaman potong. Sekitar 60 persen permintaan bunga potong domestik maupun mancanegara dapat terpenuhi (Direktorat Jenderal Bina Produksi Hortikultura, 2011). Permintaan pasar terhadap komoditas ini terus meningkat, namun sayangnya peningkatan permintaan tidak siring dengan peningkatan pendapatan yang diterima petani florikultura. Hal ini diduga akibat pasar yang tidak terstruktur, sebagaimana umumnya kondisi pasar pada komoditas pertanian.

Berdasarkan hal tersebut perlu dilakukan kajian yang lebih mendalam terhadap perilaku petani, pedagang dan konsumen akhir florikultura serta peluang pengembangan bisnis tersebut di Kabupaten Bandung Barat. Kajian dilakukan terhadap petani di hulu sampai ke 


\section{AIMBAR \\ Agribisnis}

ISSN 2460-4321

Volume 1・Nomor 2・Januari 2016

pedagang dan industri bunga potong serta konsumen di bagian hilir. Dengan demikian akan teridentifikasi para pelaku (net working), perilaku, permasalahan, dan margin di setiap titik pemasaran bunga potong di Kabupaten Bandung Barat dan kemungkinan-kemungkinan untuk menyusun suatu rantai pasokan bunga potong yang lebih ideal, sehingga petani sebagai produsen utama bunga potong memperoleh insentif harga yang layak. Hal ini penting diketahui dan dipahami, karena dalam sistem rantai pasokan bunga potong di Kabupaten Bandung Barat melibatkan banyak pelaku, mulai dari penyedia saprodi, masyarakat petani, buruh tani, pedagang perantara, pedagang di pasar bunga, eksportir, bahkan masyarakat di lingkungan kebun bunga dan lingkungan pasar bunga. Tujuan dari penelitian ini adalah: 1) Memahami perilaku petani, pedagang dan konsumen akhir florikultura serta peluang pengembangan bisnis tersebut di Kabupaten Bandung Barat serta bentuk hubungan kerja sama yang terjadi di antara pelaku, 2) Mengidentifikasi proporsionalitas pembagian keuntungan tiap mata rantai pemasaran sesuai dengan korbanan dalam menjalankan usaha dan tingkat resiko yang dihadapinya, 3) Merumuskan pola pengembangan agribisnis florikultura yang ideal di Kabupaten Bandung Barat sebagai upaya untuk meningkatkan ekonomi masyarakat.

\section{TINJAUAN PUSTAKA \\ Konsep Rantai Pasokan}

Istilah supply chain dan supply chainmanagement sudah menjadi jargon yang umum dijumpai di berbagai media baik majalah manajemen, buletin, koran, buku ataupun dalam diskusi-diskusi. Namun tidak jarang kedua term diatas di persepsikan secara salah. Banyak yang mengkonotasikan supply chain sebagai suatu software. Bahkan ada yang mempersepsikan bahwa supply chain hanya dimiliki oleh perusahaan manufaktur saja. Sebagai disiplin, supply chain management memang merupakan suatu disiplin ilmu yang relative baru. Cooper (1997) bahkan menyebut istilah "supply chain management" baru muncul di awal tahun 90-an dan istilah ini diperkenalkan oleh para konsultan manajemen. Saat ini supply chain management merupakan suatu topic yang hangat dan menarik untuk didiskusikan bahkan mengundang daya tarik yang luar biasa baik dari kalangan akademisi maupun praktisi.

Konsep Rantai Pasok atau Supply Chain Management (SCM) merupakan konsep baru dalam melihat persoalan logistik. Konsep lama melihat logistik lebih sebagai persoalan intern masing-masing perusahaan, dan pemecahannya dititikberatkan pada pemecahan secara intern di perusahaan masing-masing. Dalam konsep baru ini, masalah logistik dilihat sebagai masalah yang lebih luas yang terbentang sangat panjang sejak dari bahan dasar sampai barang jadi yang dipakai konsumen akhir, yang merupakan mata rantai penyediaan barang. SCM juga sebagai pendekatan integratif dalam menangani masalah perencanaan dan pangawasan aliran material dari pemasok sampai ke pengguna akhir. Pendekatan ini ditujukan untuk pengelolaan dan pengawasan hubungan saluran distribusi secara kooperatif untuk kepentingan semua pihak yang terlibat, untuk mengefisienkan penggunaan sumberdaya dalam mencapai tujuan kepuasan konsumen rantai pasokan.

Supply Chain Management atau rantai pengadaan adalah suatu sistem tempat organisasi menyalurkan barang produksi dan jasanya kepada para pelanggan. Rantai ini juga merupakan jaringan dari berbagai organisasi yang saling berhubungan yang mempunyai tujuan yang sama, yang sebaik mungkin menyelenggarakan pengadaan atau penyaluran barang tersebut (Djokopranoto 2002).

Prinsip utama dalam SCM ialah menciptakan sinkronisasi aktivitas-aktivitas yang beragam dan membutuhkan pendekatan holistik. Prinsip mengintegrasikan aktivitasaktivitas dalam supply chain ialah untuk menciptakan sebuah resultan yang besar bukan hanya bagi tiap anggota rantai, tetapi bagi keseluruhan sistem (Zabidi 2001). Supply chain tidak hanya meliputi manufaktur dan pemasok, tetapi juga transportasi, penggudangan, retailer, dan konsumen itu sendiri. Tujuan utama SCM adalah memuaskan kebutuhan pelanggan, bagi perusahaan adalah untuk mendapatkan keuntungan. Aktivitas supply chain dimulai dari permintaan konsumen (consumen order) dan berakhir ketika pelanggan atau konsumen telah terpuaskan (Chopra dan Meindl 2004). SCM melakukan penyerahan/pengiriman produk 
secara tepatjumlah yang lebih kecil kepada pengecer.

Perkembangan sistem yang semakin maju mempengaruhi cara mengoptimalkan supply chain sehingga mencapai manfaat yang sesungguhnya. Terdapat beberapa hal yang berkaitan dengan optimalisasi supply chain (Handoko 2003), yaitu : 1. Tuntutan pelanggan yang terus berkembang, 2. Kekuasaan retailer yang semakin besar, 3. Dilema dalam pencapaian optimalisasi, 4. Kendala dalam membangun kepercayaan, 5. Kemitraan sebagai solusi, 6. Teknologi informasi sebagai katalisator

Ada 3 macam hal yang harus dikelola dalam supply chain yaitu : Pertama, aliran barang dari hulu ke hilir contohnya bahan baku yang dikirim dari supplier ke pabrik, setelah produksi selesai dikirim ke distributor, pengecer, kemudian ke pemakai akhir; Kedua, aliran uang dan sejenisnya yang mengalir dari hilir ke hulu dan Ketiga adalah aliran informasi yang bisa terjadi dari hulu ke hilir atau sebaliknya.

\section{METODE PENELITIAN}

Penelitian ini dilaksanakan di Desa Cihideung, Kecamatan Parongpong, Kabupaten Bandung Barat, Propinsi Jawa Barat dari Bulan Oktober sampai Bulan Desember 2014. Objek penelitian ini adalah semua pelaku agribisnis florikultura dari hulu sampai hilir yang tergabung dalam Kelompok Tani Giri Mekar.Data yang dikumpulkan berupa data sekunder dan data primer. Data sekunder di peroleh dari BPS, Dinas terkait dan data kecamatan/desa. Sedangkan data primer diperoleh melalui wawancara, observasi dan pengamatan langsung di lapangan terhadap fenomena yang dikaji. Data yang dikumpulkan berupa data sekunder dan data primer. Data sekunder diperoleh dari BPS, Dinas terkait dan data kecamatan/desa. Sedangkan data primer diperoleh melalui wawancara, observasi dan pengamatan langsung di lapangan terhadap fenomena yang dikaji.

\section{HASIL DAN PEMBAHASAN \\ Model Rantai Pasokan Agribisnis Florikultura}

Dalam model rantai pasokan agribisnis Florikultura, terdapat organisasi rantai pasokan yang berhubungan dengan perusahaan atau lembaga baik secara langsung maupun tidak langsung melalui pemasok atau pelanggannya dari point of origin hingga point of consumption. yang berhubungan dengan perusahaan atau lembaga baik secara langsung maupun tidak langsung melalui pemasok atau pelanggannya dari point of origin hingga point of consumption. Anggota rantai pasokan agribisnis florikultura terdiri dari petani, penangkal, petani bunga potong, pengumpul/tengkulak bunga pot, pengumpul/tengkulak bunga potong, pedagang pasar bunga, dekolator dan konsumen pengguna. Model rantai pasokan komoditas florikultura tersebut, secara lengkap disajikan pada Gambar 1.

Pada Gambar 3.1, dapat diketahui bahwa ada dua jenis produk yang dihasilkan oleh petani florikultura di kelompok Tani Giri Mekar, yaitu 1) bunga pot dan 2) bunga potong. Berdasarkan jenis produk yang dihasilkan, maka masing-masing mempunyai anggota organisasi yang berbeda.

Organisasi pada rantai pasok bunga pot terdiri dari: 1) sarana produksi (kios pertanian), 2) petani penangkar bunga, 3) petani bunga pot, 4) pengumpul bunga pot, 5) ritel bunga pot, 6) dekorator, dan 7) konsumen. Hampir sama dengan organisasi pada rantai pasokan bunga pot, maka organisasi rantai pasok bunga potong terdiri dari; 1) sarana produksi (kios pertanian), 2) petani bunga mawar potong, 3) pengumpul bunga potong, 4) pedagang pasar bunga potong, 5) ritel bunga potong, 6) dekolator, dan 7) konsumen.

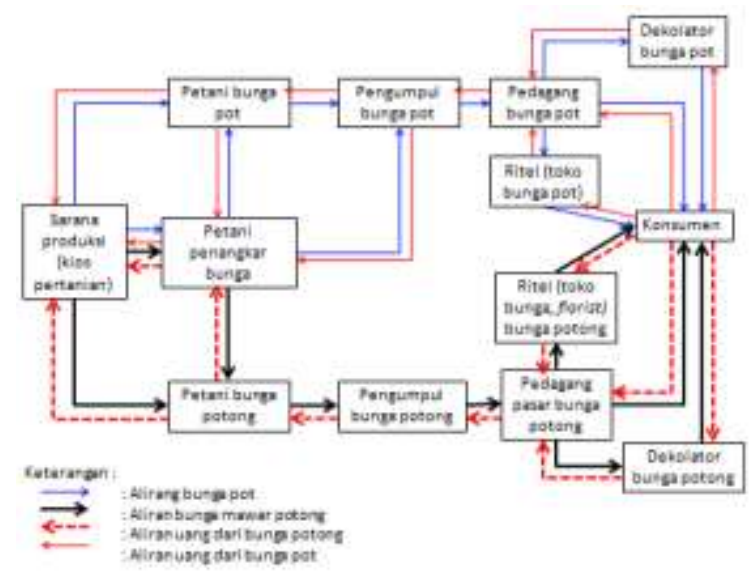

Gambar 1 Model Rantai Pasokan Agribisnis Florikultura di Kelompok Tani Giri Mekar Desa Cihideung, Kecamatan Parongpong, Jawa Barat 


\section{AIMBAR \\ Agribisnis}

ISSN 2460-4321

Volume 1・Nomor 2・Januari 2016

\section{Peta Aliran dalam Rantai Pasokan Agribisnis Florikultura}

Dalam rantai pasokan komoditas florikultura, terdapat aliran barang dan aliran uang. Aliran barang berupa; 1) aliran produk berupa bunga pot dan bunga mawar potong, dan 2) aliran uang, yaitu: 1) aliran produk dan 2) aliran uang. Aliran produk berupa bunga pot dimulai dari kios pertanian yang menyediakan saranan produksi sampai dengan konsumen pengguna produk florikultura, seperti disajikan pada Gambar 2.

Aliran produk bunga potong sama dengan aliran produk bunga pot, yang membedakan adalah jenis produk florikultura yang dijual. Petani bunga pot, menjual produknya dalam bentuk bunga hias yang ditanam di dalam pot atau polibag, sedangkan petani bunga potong, jenis produk yang dijual adalah berupa bunga mawar yang dipotong dari batangnya. Aliran produk bunga mawar potong seperti yang terlihat pada Gambar 3.

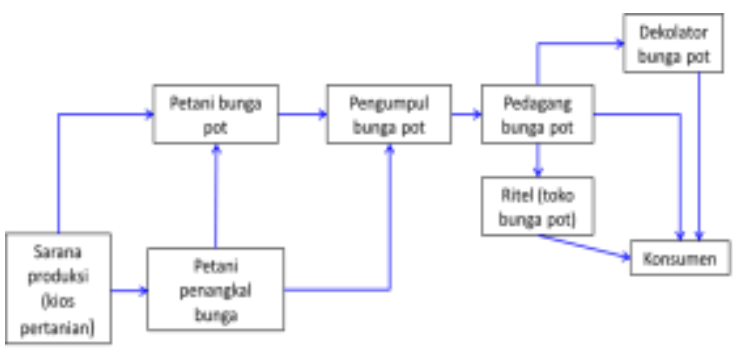

\section{Gambar 2 Aliran Produk Bunga Pot dalam Rantai Pasokan Agribisnis Florikultura di Kelompok Tani Giri Mekar}

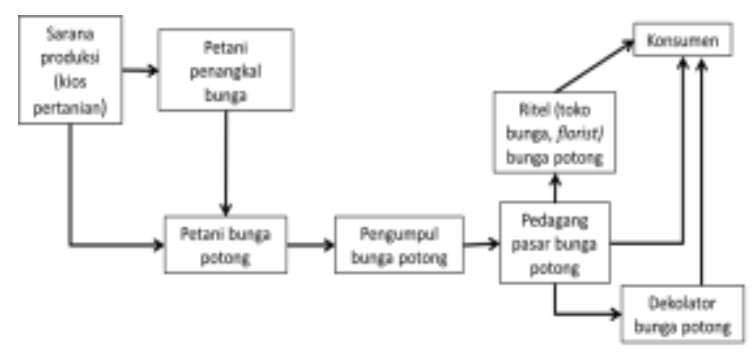

Gambar 3. Aliran Produk Bunga Mawar Potong dalam Rantai Pasokan Komoditas Florikultura di Kelompok Tani Giri Mekar

Seperti yang sudah disebutkan di atas, bahwa di samping aliran produk (bunga pot dan bunga potong), dalam rantai pasokan komoditas hortikultura di Kelompok Tani Giri Mekar juga terdapat aliran uang. Peta aliran uang dari bunga pot dan bunga mawar potong dalam rantai pasokan komoditas hortikultura ini disajikan pada Gambar 4 dan Gambar 5.
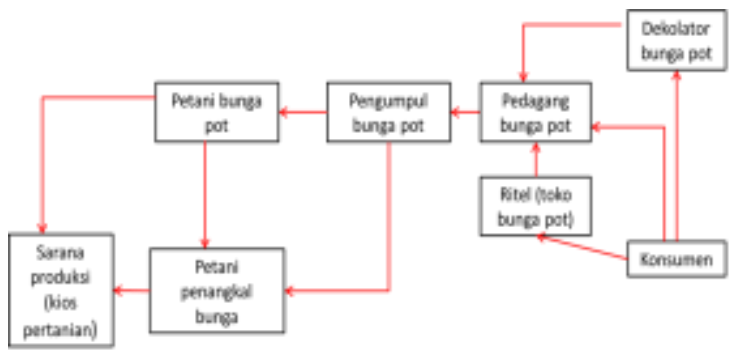

Gambar 4. Aliran Uang Bunga Pot dalam Rantai Pasokan Komoditas Florikultura di Kelompok Tani Giri Mekar

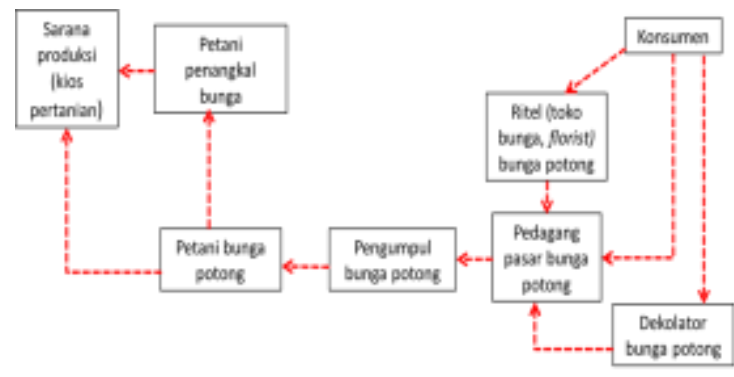

Gambar 5. Aliran Uang Bunga Mawar Potong dalam Rantai Pasokan Komoditas Florikultura di Kelompok Tani Giri Mekar

Setiap pelaku dalam rantai pasokan bunga pot mempunyai fungsi yang berbeda-beda. Masing-masing melakukan aktifitas untuk mendukung kelangsungan usahanya tersebut. Aktivitas yang dilakukan oleh salah seorang pelaku sangat ditentukan oleh aktivitas pelaku lainnya. Dengan kata lain dapat dinyatakan bahwa aktifitas para pelaku agribisnis komoditas florikultura ini saling mempengaruhi secara interdependen. Seorang pelaku tidak dapat bertindak sendiri tanpa ada aktivitas dari pelaku yang lain.

\section{Rancang Model Kebijakan}

Berdasarkan hasil analisis rantai pasokan agribisnis florikultura yang sudah diuraikan di atas, maka dapat disusun rancang model kebijakan yang memberikan solusi terhadap permasalah yang dihadapi oleh para pelaku, terutama petani sebagai produsen. Model yang dirancang meliputi model penguasaan lahan petani, model pembiayaan dan model adopsi 
teknologi. Model ini disajikan dalam bentuk digram sebab akibat. melalui diagram ini akan dapat diperlihatkan variabel-variabel kunci dalam rantai pasokan agribisnis florikultura tersebut. Diagram sebab akibat secara lengkap disajikan pada Gambar 6.

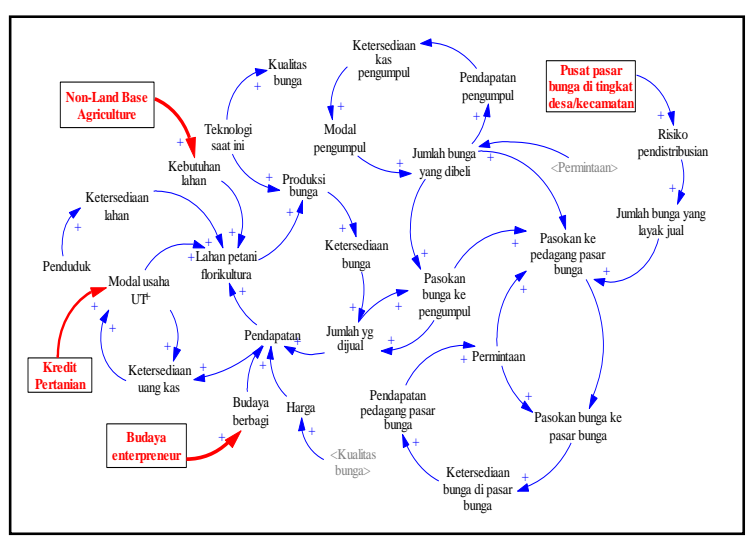

Gambar 6. Diagram Sebab Akibat dalam Sistem Rantai Pasokan Agribisnis Florikultura di Kelompok Tani Giri Mekar

\section{PENUTUP}

\section{Kesimpulan}

Berdasarkan hasil kajian, analisis dan deskripsi dari penelitian ini, maka dapat ditarik beberapa kesimpulan sebagai berikut:

1. Petani bunga polybag melakukan usahanya dengan menyewa lahan untuk menempatkan polybag dan hanya menggunakan tenaga kerja rumahtangga (istri). Sedikit sekali petani yang memiliki lahan sendiri untuk berusahatani. Mereka menjual bunga polybag ke pengumpul yang sebagian besar masih ada hubungan keluarga, sehingga masalah harga dan jangka waktu pembayaran tidak menjadi kendala. Bargaining position mereka sangat lemah, sehingga keuntungan yang diperoleh sangatkecil, namun mereka tetap bertahan dengan usahanya karena menanam bunga sudah menjadi bagian kehidupan mereka. Prinsip yang mereka pegang adalah "kemauan keras untuk menanam bunga, maka uang akan diperoleh".

Pelaku lain pada organisasi rantai pasokan bunga polybag terutama pedagang bunga memperoleh keuntungan yang lebihtinggi, selain risiko usaha yang dihadapi lebih tinggi. Mereka memiiki bargaining position yang lebih tinggi pula dan mereka berhubungan langsung dengan konsumen.
Petani bunga mawa potong mengusahakan komoditasini di green house. Pengusahaan bunga mawar potong tergolong rumit, sehingga membutuhkan keterampilan dan kesabaran. Modal usaha yang dibutuhkan untuk memulai usaha bunga mawar potong juga banyak, terutama untuk biaya membangun green house.

2. Pada agribisnis bunga polybag, persentase keuntungan terendah dimiliki oleh petani penangkar bibit bunga dan petani bunga polybag. Kondisi ini menunjukkan bahwa bargaining position mereka sangat lemah. Demikian juga dengan agribisnis bunga mawar potong, keuntungan terendah dimilik oleh petani penangkar bibit dan petani bunga mawar potong. Sebaliknya keuntungan terbesar untuk bunga polybag dan bunga mawar potong dimiliki oleh ritel (toko bunga). Fenomena ini membuktikan bahwa pasar komoditas florikultura di Kabupaten Bandung Barat merupakan pasar yang tidak terorganisir. Pasar yang terorganisir sangat dibutuhkan untukmeningkat kan pendapatan petani dan masyarakat secara umum di Desa Cihideung.

3. Pola pengembangan agribisnis florikultura di Kabupaten Bandung Barat sebaiknya menata pasar komoditas ersebut. Rantai pasokan yang kurang efisien bisa ditata menjadi efisien. Salah satunya adalah dengan membangun pasar bunga di sentra produksi komoditas florikultura yaitu di Desa Cihideung. Dengan demikian maka rantai pasokan bunga polybag dan bunga mawar potong tidak terlalu rumit. Hal ini terwujud tentu dengan danya campu tangan pemerintah, baik di tingkat kabupaten maupun provinsi melalui kebijakan dan program-program.

\section{Saran}

1. Pengembangan agribisnis florikultura hendaknya melibatkan semua pihak, bukan hanya pelaku usaha tetapi juga pemeintah.

2. Perlu penelitian lebih lanjut tentang strategi rencana pengembangan agribisnis florikultura yang lebih komprehensif sehingga dapat menjadi acuan untuk menjadikan Desa Cihideung menjadi desa klaster florikultura. 


\section{MIMBAR A GRIBISNIS \\ ISSN 2460-4321}

Volume 1・ Nomor 2・ Januari 2016

\section{DAFTAR PUSTAKA}

Acedo, A.L., and Kanlayanarat. 2001. Handling system for ornamental crops. Post harvest handling system of agricultural products. Division of Postharvest Technol. King Mangkut Univ. of Technol. Thonbury, Bangkok.

Anonim, 2013. Hortikultura (http://dipertanhut.purworejokab.go.id/inde x.php ?option $=$ com_content $\&$ view $=$ article $\&$ id $=7$ 6: statistik-hortikultura\&catid $=63$ :laporanbulanan-hortikultura\&Itemid=138) akses pada tanggal 13 desember 2014

BPEN. 2004. Prospek bisnis anggrek masih menjanjikan.

Melalui< http://www.nafed.go.id/indo > [20/01/05]

Chopra S, Meindl P. 2004. Supply Chain Management : Strategy Planning, and Operation. USA:

Djokopranoto R. 2002. Konsep Manajmenen Supply Chain. Jakarta: PT. Grasindo.Pearson Prentice Hall.

Dinas Pertanian, Tanaman Pangan dan Hortikultura. 2011. Perkembangan Produksi Horikultura Jawa Barat. Dispertan Jawa Barat.

Handoko TH. 2003. Manajemen Produksi dan Operasi. Edisi Ketiga. Yogyakarta: BPFEYogyakarta.

Kahar,A. 1997. Petunjuk Praktikum Silvikultur. Departemen Silvikultur Kehutanan Bogor: IPB.

Tambunan, Tulus T.H. (1996), Perekonomian Indonesia. Jakarta: Ghalia Indonesia

Zabidi Y. 2001. Supply Chain Management : Teknik Terbaru dalam Mengelola Aliran Material/Produk dan Informasi dalam Memenangkan Persaingan. Jurnal Nasional. Surabaya: Institut Teknologi Surabaya. 